\title{
Epidemiological study and identification of some flea species infesting wild rabbits (Oryctolagus cuniculus) and cape hares (Lepus capensis) in northern Algeria
}

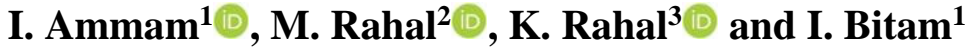 \\ ${ }^{1}$ Laboratory of Biodiversity and Environment, Interactions, Genome, University of Sciences and Technology Houari \\ Boumedienne, Algiers, ${ }^{2}$ Department of Biology, University of Yahia Fares, Medea, ${ }^{3}$ Institute of Veterinary Sciences, \\ University of Blida, Blida, Algeria
}

\begin{tabular}{l} 
Article information \\
\hline Article history: \\
Received February 18, 2021 \\
Accepted May 04, 2021 \\
Available online November 23, 2021 \\
\hline Keywords: \\
Algeria \\
Cape hare \\
Ectoparasites \\
Fleas \\
Wild rabbit \\
\hline
\end{tabular}

\section{Correspondence:}

I. Ammam

imiammam@gmail.com

\begin{abstract}
Wild rabbit (Oryctolagus cuniculus) and cape hare (Lepus capensis) are hosts for different flea species and have high medical and veterinary importance, fleas of wild leporids are of special concern since they can act as vectors for diseases, including zoonoses. This study was designed to identify flea species infesting these animals with the description of their epidemiology and the assessment of factors influencing their infestation importance in five provinces located in northern Algeria, to evaluate their implication in the transmission of pathogens. In total, 86 wild leporids were checked from July 2014 to September 2020. Fleas were collected from the fur of animals with tweezers and identified using appropriate keys. The findings showed that 32/86 (37.2\%) of animals were infested with fleas. Four flea's species were identified on cape hares Ctenocefalides felis (51.06\% of fleas identified), Ctenocefalides canis 34.04\%, Spilopsyllus cuniculi $10.63 \%$, and Archaeopsylla erinacei $4.25 \%$, with a seasonal peak in December. The same, four flea species were found parasitizing wild rabbits Spilopsyllus cuniculi $90.7 \%$, Ctenocefalides felis $4.65 \%$, Ctenocefalides canis $2.32 \%$, and Pulex irritans $2.32 \%$, with the highest importance in March and April. Moreover, this study showed no influence of female gestations on the rate of flea hare infestations. However, $S$ cuniculi rate was correlated with the breeding cycle of the wild rabbits. These findings revealed that, the temperature and the humidity can be important factors that influence on wild leporids flea infestation.
\end{abstract}

DOI: 10.33899/ijvs.2021.129596.1665, (CAuthors, 2022, College of Veterinary Medicine, University of Mosul.

This is an open access article under the CC BY 4.0 license (http://creativecommons.org/licenses/by/4.0/).

\section{Introduction}

Wild rabbit (Oryctolagus cuniculus) and cape hare (Lepus capensis) belong to the family Leporidae and are widespread in Algeria (1). They are one of the most popular game animals (1). These wild leporids are known as potential reservoirs for many zoonotic pathogenic agents, including tularemia (Francisella tularensis), plague (Yersinia pestis), pasteurellosis (Pasteurella multocida), ringworm (Trichophyton spp.), and cryptosporidiosis
(Cryptosporidium cuniculus) (2). Additionally, can be also a host to several external parasites including fleas (Insecta, Siphonaptera) (1), which are obligate hematophagous insects (3). Like other ectoparasites present on hares and wild rabbits, they suck blood and cause irritation and anemia when found in significant amounts on the host $(4,5)$. In addition, these parasites play important role as disease vectors and can spread certain pathogenic agents to animals and humans (4). Ctenocefalides felis and Ctenocefalides canis are carriers of Rickettsia.felis and Barttonella spp (6), 
and the role of Pulex irritans in the transmission of the plague was confirmed (6). While Spilopsyllus cuniculi is an important vector of rabbit myxomatosis (7). It is also the vector of Trypanosoma nabiasi (7) and Francisella.tularensis (8). More, both S. cuniculi and Xenopsylla cunicularis have been proofed to transmit rabbit haemorrhagic disease in the laboratory (9), this viral disease is serious and extremely contagious to the wild rabbits. Morbidity and mortality rates are high in unvaccinated animals; the agent pathogen responsible was Lagovirus (family Caliciviridae) includes several viruses pathogenic for lagomorphs. Rabbit Hemorrhagic Disease Virus (RHDV) cause rabbit hemorrhagic disease, while European Brown Syndrome Virus (EBHSV) causes European brown hare syndrome (9). Efficient surveillance of these hematophagous arthropods to minimize the occurrence of disease, or also, their possible utility as «living syringes » to propagate attenuated strains of viruses to vaccinate the wild lagomorphs (10). It relies on understanding the ecology, distribution, and seasonal patterns of the different species (11). Actually no scientific research or published data were reported about infestation of wild leporids with fleas in Algeria or even in some the Northern African countries. However, Launay (12) reported as general information about Xenopssylla cunicularis flea species found on wild rabbits in Morocco and S. cuniculi has also been identified in many Moroccan cities (3).

The present study was designed to describe the patterns of seasonal abundance for each leporid flea species identified in Northern Algeria, as well, to observe the cycle breeding effects on the dynamic of these ectoparasites in natural wildlife. In particular, we were interested in the investigation whether the flea species infesting wild rabbits and hares could represent a potential risk for human and animal health in Algeria.

\section{Materials and methods}

\section{Study area}

This study was carried out in five provinces from Northcenter Algeria: Tipaza, Ain El Defla, Medea, Blida and Algiers. These provinces include mountains, hills and, plains with a Mediterranean climate, which are characterized by an average rainfall of $600-800 \mathrm{~mm}$ per year, also an average annual temperature of $18^{\circ} \mathrm{C}$ in the littoral and $25^{\circ} \mathrm{C}$ in the inner wilayas. The humidity average in humid forests exceeds $70 \%$.

\section{Samples}

Between July 2014 and September 2020. A total of 86 leporids were collected: 45 cape hares (Figure 1) and 41 wild rabbits (Figure 2), each animal was separately packed in a nylon bag and brought to the parasitology laboratory of the Institute of Veterinary Sciences (University of Blida 1). Subsequently a questionnaire was completed for each leporid, with information on the age (adult /young), sex (male/ female), region, collection period and pregnancy or lactating state were recorded during the survey, the distribution of hares and wild rabbits is shown according to months in. The leporids were examined for fleas macroscopically as other ectoparasites $(13,14)$. Which were abstracted using fine forceps and then kept in $70 \%$ ethanol. At the laboratory, fleas were identified using morphological keys (3).

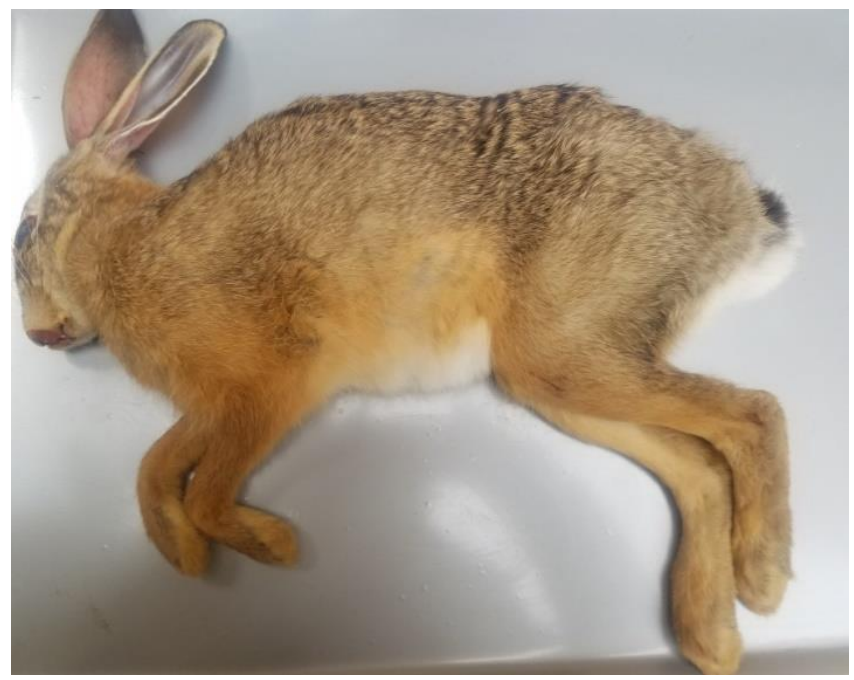

Figure 1: Cape hare (Lepus capensis).

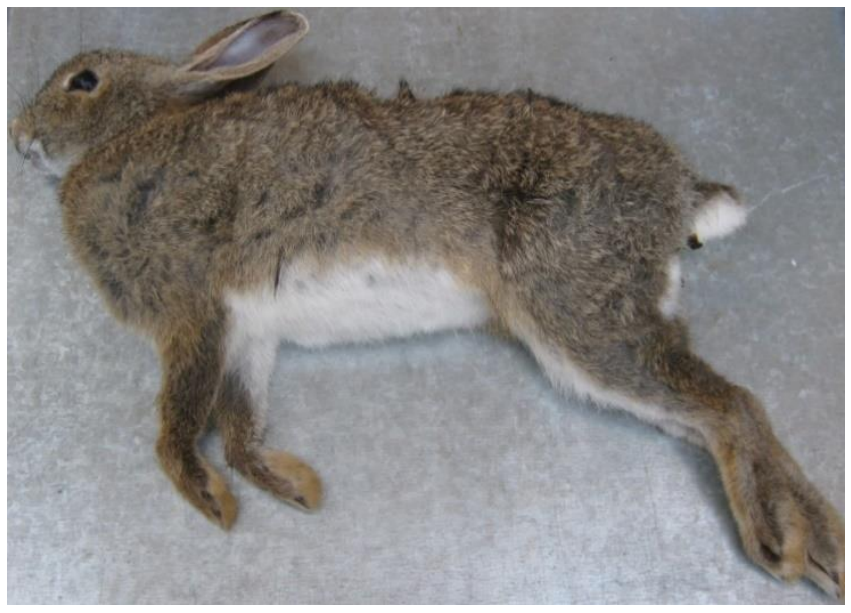

Figure 2: Wild rabbit (Oryctolagus cuniculus).

\section{Statistical analysis}

The first analysis determines the classical ecology indices for each survey group (in our case are: fleas), parasitological terms used are prevalence, mean intensity, intensity and mean abundance that were recommended by Bush et al. and Hatem et al. $(15,16)$. Graphic treatments of the study were conducted by Excel 2010. 


\section{Results}

A variable number of wild leporids were collected depending on the collaboration of hunters and on their abundance in the study site (Table 1). In total, 32 (37.2\%) of animals were found to be parasitized with fleas, the results showed that 18 of $45(40 \%)$ cape hares and 14 of $41(34.1 \%)$ wild rabbits were infested by fleas. The numbers of this ectoparasite recovered from the wild leporids, the prevalence of infestation, abundance, and the mean intensity are summarized in (Table 2 and 3 ).

Table 1: Wild rabbits and hares information

\begin{tabular}{lccccccccc}
\hline \multirow{2}{*}{ Region } & \multirow{2}{*}{ Period } & \multicolumn{2}{c}{ Leporid numbers } & \multicolumn{2}{c}{ Sex } & \multicolumn{2}{c}{ Age } & \multicolumn{2}{c}{$\begin{array}{c}\text { Pregnant numbers } \\
\text { of female leporid }\end{array}$} \\
\cline { 2 - 10 } & & Hares & Wild & Female & Male & Mature & Young & Hare & Wild \\
\hline Tipaza & Aug 2014- Sep 2020 & 35 & 34 & 22 & 7 & 49 & 20 & 11 & 3 \\
Blida & Mar 2018, Aug 2020 & 5 & 5 & 3 & 7 & 8 & 2 & 2 & 0 \\
Ain El Defla & Oct- Dec 2014 & 2 & 2 & 1 & 3 & 4 & 0 & 1 & 0 \\
Medea & Jul - Nov 2014 & 2 & 0 & 0 & 2 & 2 & 0 & 0 & 0 \\
Algiers & Mar 2018 & 1 & 0 & 1 & 0 & 1 & 0 & 1 & 0 \\
\hline
\end{tabular}

a. except 2017 and 2018 period.

Table 2: Results of flea which infested the hares in collecting area

\begin{tabular}{lcccccc}
\hline Species & $\begin{array}{c}\text { No of infested hares } \\
\text { / collected hares }\end{array}$ & $\begin{array}{c}\text { No and rate of } \\
\text { identified fleas }\end{array}$ & Prevalence & Abundance & Intensity & $\begin{array}{c}\text { Mean } \\
\text { intensity }\end{array}$ \\
\hline C. felis & $13 / 45$ & $24 / 47(51.06 \%)$ & $28.88 \%$ & 0.53 & $1-4$ & 1.33 \\
C. canis & $6 / 45$ & $16 / 47(34.04 \%$ & $13.33 \%$ & 0.35 & $1-6$ & 0.88 \\
S. cuniculi & $3 / 45$ & $5 / 47(10.63 \%)$ & $6.66 \%$ & 0.11 & $1-3$ & 0.27 \\
A. erinacei & $1 / 45$ & $2 / 47(4.25 \%)$ & $2.22 \%$ & 0.04 & $0-2$ & 0.11 \\
\hline
\end{tabular}

Table 3: Results of flea which infested the wild rabbits in collecting area

\begin{tabular}{lcccccc}
\hline Species & $\begin{array}{c}\text { No of infested wild } \\
\text { / collected wild }\end{array}$ & $\begin{array}{c}\text { No and rate of } \\
\text { identified fleas. }\end{array}$ & Prevalence & Abundance & Intensity & $\begin{array}{c}\text { Mean } \\
\text { intensity }\end{array}$ \\
\hline S. cuniculi & $13 / 41$ & $39 / 43(90.70 \%)$ & $31.71 \%$ & 0.91 & $1-13$ & 2.78 \\
C. canis & $1 / 41$ & $1 / 43(2.32 \%)$ & $2.43 \%$ & 0.02 & $0-1$ & 0.07 \\
C. felis & $1 / 41$ & $2 / 43(4.65 \%)$ & $\{.70 \%$ & 0.04 & $0-2$ & 0.14 \\
P. irritans & $1 / 41$ & $1 / 43(2.32 \%)$ & $2.43 \%$ & 0.02 & $0-1$ & 0.07 \\
\hline
\end{tabular}

Four flea species were identified in cape hares. C.canis (Figure 3), S. cuniculi (Figure 4), A.erinacei (Figure 5), and C. felis (Figure 6) that was the most abundant identified flea. Four species were also recovered in wild rabbit $C$. canis, C. felis, and P. irritans (Figure 7) and with the abundance of $S$. cuniculi. Three of the 18 hares were also infested with two flea species, and only one hare was parasitized with three species (C.felis, S.cuniculi, A erinacae) in the same animal. Although, two of the 14 wild rabbits were infested with two flea species during the study.

The seasonal abundances and the flea numbers on the hares and the wild rabbits investigated are graphically presented in (Figures 8 and 9), respectively. We observed in hares that the highest number of infesting fleas was recorded during December for both flea species C.felis (24/ 47 fleas collected) and C. canis (16/47 of total fleas) (Figure 10) and, we also noted the uppermost rate of S. cuniculi, (the most abundant flea species in wild rabbits) was reported in March and April (Figure 9). However, one pregnant female hare was infested with $\mathrm{S}$. cuniculi in August and two other hares in March.

The number of the pregnant hare females (Table 1) is illustrated graphically in (Figure 11). The breeding appeared to take place throughout the year, with a seasonal peak of pregnancy in October. In the case of wild rabbits, we found only three pregnant females which were infested by fleas (S.cuniculi), one female was observed in October and two others in March. In fact, no influence of female pregnancy on the rate of flea infestation hares was observed. However, S.cuniculi infestation was correlated with the wild rabbits breeding cycle. 


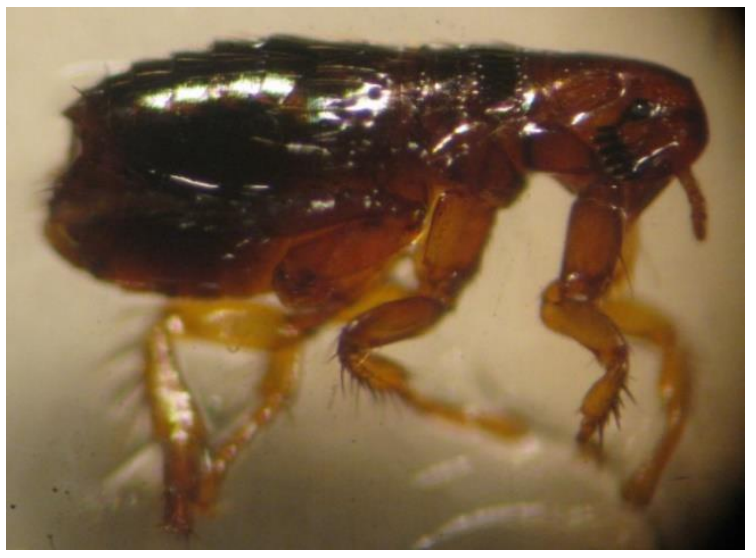

Figure 3: Spilopsyllus cuniculi female.

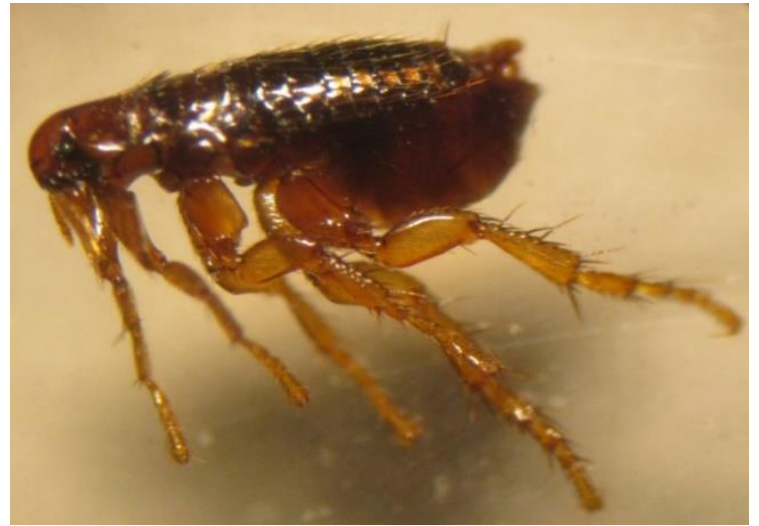

Figure 4: Ctenocephalides canis male.

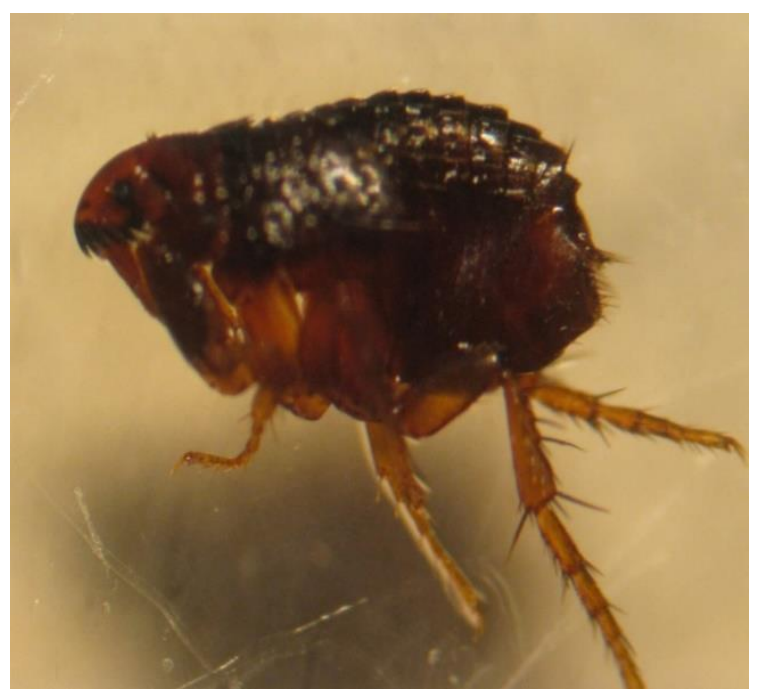

Figure 5: Ctenocephalides felis female.

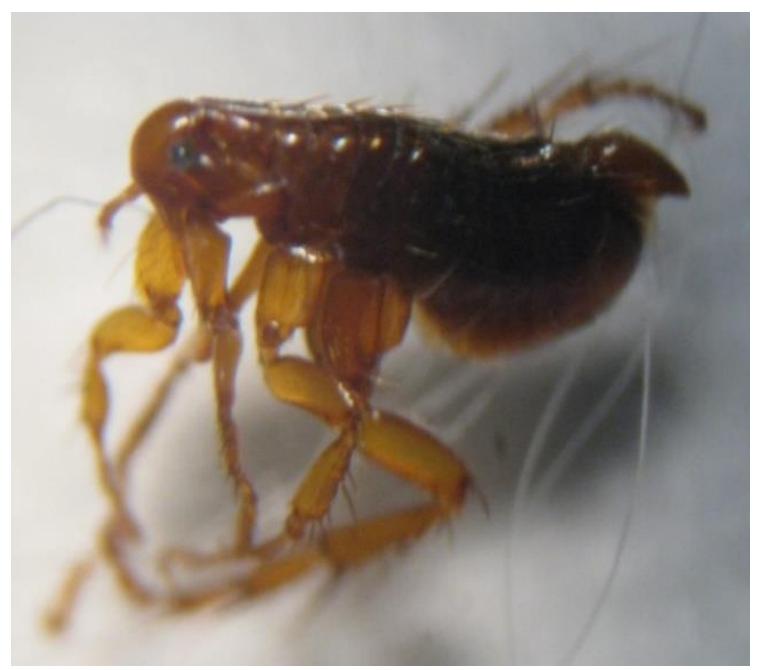

Figure 6: Archaeopsylla erinacei male.

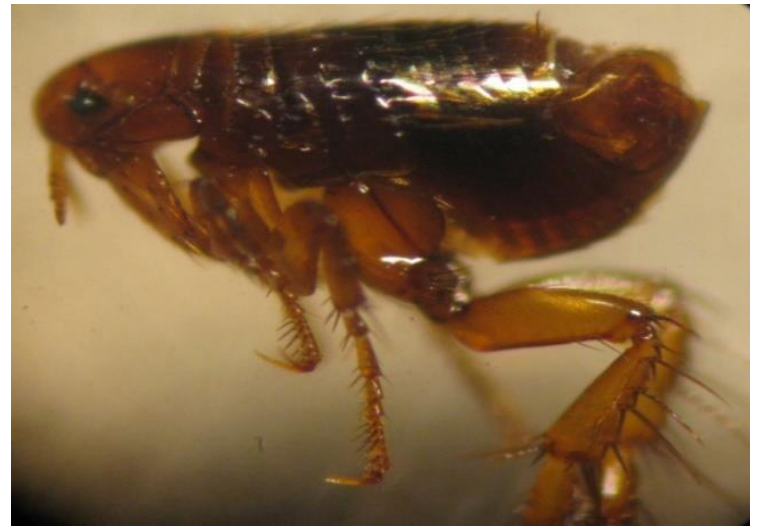

Figure 7: Pulex.irritans male.

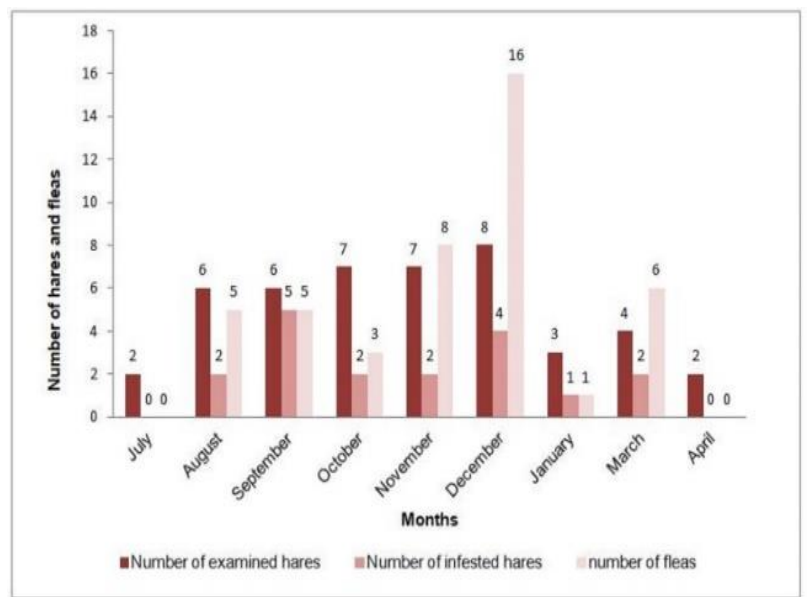

Figure 8: Distribution, infestation rates and fleas number of the hares according to the months. 


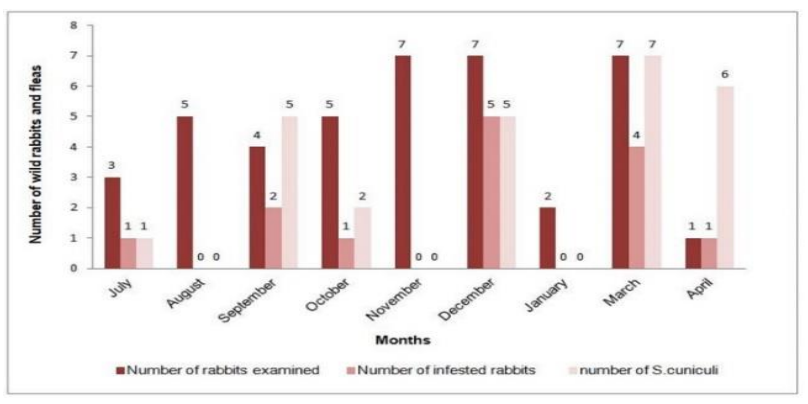

Figure 9: Distribution, infestation rates and, fleas number (S.cuniculi most abundant flea) of the wild rabbits according to the months.

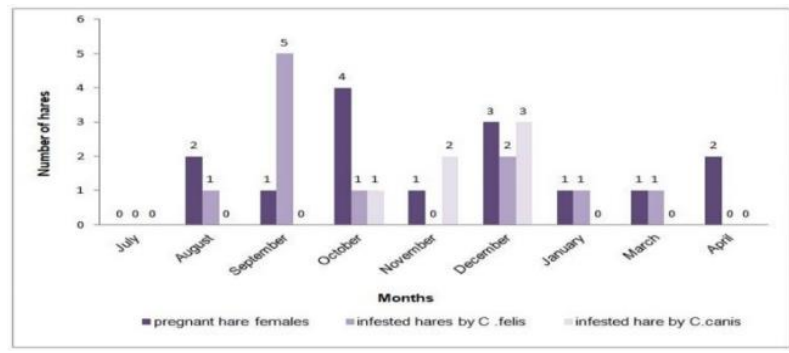

Figure 10: Distribution and number of flea species of the hares according to the months.

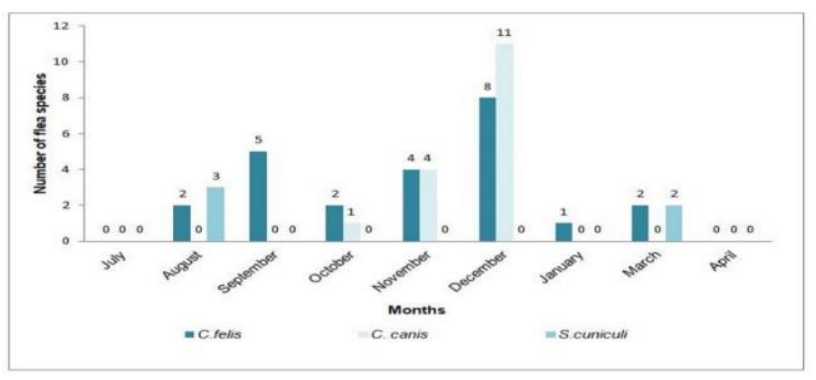

Figure 11: Monthly reproductive status of cape hare females according to infested hares with flea species were identified during the collection months.

\section{Discussion}

In the present study, fleas associated with cape hares and wild rabbits were studied in different localities in the North-center of Algeria. The results indicate that hares are considered as host for four species of fleas C. canis, $S$. cuniculi, A. erinacei and $C$. felis which represent the most abundant flea (24/ 47 fleas collected), and, to a lesser extent, C. canis (dog flea) (16/47 of total fleas). A few S.cuniculi, a common flea of rabbits, were present in 3 hares and one hare was infested by two species of $A$. erinacei (hedgehog flea). Among the 41 wild rabbits were examined, we found also four flea species. However, a single species, $S$. cuniculi that was responsible for almost flea infestations on the wild rabbits. A single species of P.irritans and C.canis were recovered from separate animals, and two $C$. felis from another rabbit. These aberrant infestations in wild leporids possibly arisen as a result of intrusion or habitat sharing by the various hosts and is a natural phenomenon (17). Fleas are cosmopolitan ectoparasites that live in various different host species. The usual hosts of $S$. cuniculi are domestic rabbits and hares (18). Mead-Briggs and Page quoted 14 flea species, including P. irritans and N. fasciatus, as well as S. cuniculi, infesting rabbits in Great Britain (18). In Victoria, Australia $N$. fasciatus was also recorded from one wild rabbit (Oryctolagus cuniculus) (18), whereas, the hares were infested by E.myrmecobii, S.cuniculi and one C.canis were detected on one young female hare in two regions of Victoria (19). P. irritans were found on wild rabbits in the United States (18) and Canada (18). In Germany, Frank et al. (8) reported an $86 \%$ infestation prevalence of 50 wild rabbits by S.cuniculi. While, in Spain, five flea species were identified on wild rabbits S.cuniculi, X.cunicularis, Echidnophaga iberica, Caenopsylla laptevi and P.irritans (11). Another study in South Africa cited four flea species, C. felis damariensis, E. gallinacea, E. larina, and Dinopsyllus sp, on scrub hares and C. Felis damariensis was the most widely distributed species on the hares (17). In Kenya, Flux found that Lepus capensis was most frequently parasitized with $C$. felis strongylus and $E$. gallinacea (17). So far, two flea species, $S$. cuniculi and $C$. canis, had been reported on rabbits in Turkey (18). Also, another study in Konya, Turkey, $P$. irritans and, $N$. fasciatus were detected, while neither $S$. cuniculi and $C$. canis nor other flea species could be present on the hares, and $P$. irritans was the most dominant flea species (18). During December, the highest number of fleas was recorded, the decline in flea numbers coincided with a rise in temperature at a period when there was little to no rain, even the low number of fleas and low infestation prevalence recorded during the summer, the current survey suggests that high temperature is possibly a more significant climate factor restricting flea infestations on cape hares. Similar to the findings presented by Louw et al. (17) in South Africa on the scrub hare, the prevalence and abundance of flea reached peaks between August and October when temperatures decreased steadily and afterwards to their lowest values between February and April, with an increase in temperature. Cooke (20) demonstrated that fleas in the wild are adapted to low humidity levels. For example, Xenopsylla cunicularis, the wild European rabbit flea, can live at $50 \%$ relative humidity (17). S.cuniculi was the most prevalent wild rabbit flea species identified in our survey. This flea is the only species that favors moderately moist climatic regions (11), which explains the prevalence of this flea species on their animal host in our sample, since the study sites were damp, as well 
as flea rabbits, were wholly reliant on steroid hormones circulating in pregnant female (17). In fact, rising estrogen and corticosteroid levels at the end of the host pregnancy trigger the reproduction of flea, which lay their eggs in the nest. Hatched flea larvae ingesting adult flea feces containing dried blood (8). Rothschild and Ford (17) reported that the ovaries of female Cediopsyla simplex, a flea infesting rabbits and hares in North America, only formed when the flea fed on either pregnant female or newborn rabbits. The resorption of all developing oocytes and the quick regression of the female flea ovaries were caused by feeding on the pregnant doe. Thus the breeding cycles of these flea species are correlated with the arrival of the leverets, which they then parasitize (17). The effect of reproduction on flea dynamics was shown by our findings, since the large number of wild rabbits infested by $S$. cuniculi in March and April, coincided with the reproduction period. We revealed also, the infestation with flea rabbit on the hare was in March and on a gravid female hare in August. However, in the present study, there was no influence of hare pregnant females on the increase numbers of C. felis and C.canis species. In Algeria, C.felis, C.canis, and $A$. erinacei have been found naturally infected by pathogens causing disease in humans, and animals including Rickettsia felis, Bartonella henselae (7). Furthermore, wild leporids shared the same habitat as other wild animals, such as wild boars, wild carnivores, and birds. This ecological diversity resulted in the exchange of vector parasites including, fleas and their pathogens which can be transmitted. As example, Ctenocefalides felis (cat flea), all mammals living in the same biotope are susceptible to be infested by $C$. felis (3). Its host specificity is low; thus, it can be found on other animals, including small ruminants, cattle, primates, rodents, poultry and even opossum (7), this flea can transmit R.felis, B.henselae and B. clarridgeiae (21). Ctenocefalides canis is also renowned as the (dog flea), this is a species that is sedentary on its host and infests primarily domestic and wild canids. The red fox is its main host, but epidemiological studies have shown that $C$. canis can also be present on cats, but with a lower prevalence than C. felis (7), Bitam et al. (22) also proved the presence of $R$. felis for the first time in this flea species collected from rodents in Oran, Algeria. Archaeopsylla erinacei (hedgehog flea) but it can also infest dogs (7). A current epidemiological survey carried out in Algeria, showed a prevalence of $72 \%$ of $R$. felis detecting in A. erinacei obtained from hedgehogs (23). This flea is the pulicosis agent, whereas some researchers have recently identified other pathogens in this species, such as, a novel rickettsia genotype Rickettsia helvetica and $B$. henselae (24). Pulex irritans are referred to as the (human flea). However, this species often infests a wide range of hosts, such as large wild mammals and rodents, but seldom present on rats (7). Blanc and Baltazard (1945) long presumed the role of $P$. irritans in the propagation of the plague in Morocco (7). Nine tests were performed with naturally infected P.irritans on the plague victims. This experiment allowed the authors to state that infected human fleas could spread disease (7). The flea $S$ cuniculi is a popular parasite of European rabbits, but, it can be also present on cats (7), it may transmit Francisella tularensis, which causes tularemia (8). Some authors have confirmed the existence of two flea species, S. cuniculi and Xenopsylla cunicularis, in sustaining the Bartonella alsatica infection in wild rabbits over the year (25). This flea is also associated with dermatitis in cats, feline and canine leishmaniosis (7), and can be the main vector of myxomatosis which was previously used to control rabbit populations in France and Australia (7), but, all attempts failed (8).

\section{Conclusion}

In Algeria, the wild rabbits (Oryctolagus cuniculus) and Cape hare (Lepus capensis) are a major host for C.felis, C.canis, S.cuniculi, P.irritans and, A. erinacei, This result shows the rich mix of medical and veterinary interest species that make up the wild lagomorph flea population in Northern Algeria. The host presence is a major factor determining the level of environmental flea infestation. Also, the climatic factors as temperature and humidity can be important factors that influence on flea infestation in the wildlife. Further studies to assess whether these fleas could limit the survival and fitness of wild leporids and, therefore, affect their conservation status are needed. Moreover, it is necessary to investigate whether fleas associated with hares and wild rabbits are infected by pathogenic organisms of medical and veterinary concern.

\section{Acknowledgements}

We wish to express our thanks to the forests conservation staff of Tipaza province for their valuable help with the fieldwork. We are grateful to all hunters for their participation in the specimen collections and the general Directorate of Forests at the Ministry of Agriculture, Rural Development and Fisheries that made administrative facilities for capturing wild leporids in Algeria.

\section{Conflict of interest}

The authors assert that there are no conflicts of interest with other researchers or institutions

\section{References}

1. Nowak R . Order lagomorpha in mammals of the world. $6^{\text {th }}$ ed. London: Johns Hopkins University press; 1999. 1715-1738 p.

2. Sato S, Brinkerhoff RJ, Hollis E, Funada S, Shannon AB, Maruyama S. Detection of zoonotic Bartonella pathogens in rabbit fleas, 
Colorado, USA. Emerg Infect Dis. 2020;26(4):778-781. DOI: 10.3201/eid2604

3. Beaucournu JC, Launay H. Les puces (Siphonaptera) de France et du bassin méditerranéen occidental. Fédération Française des Sociétés de Sciences Naturelles, Paris. 1990; 548 p.

4. Franc M. Puces et methodes de lutte. Rev Sci Tech Off Int Epiz. 1994;13(4):1019-1037. [available at]

5. Bahzad M. Detection on ectoparasites on small ruminants and their impact on the tanning industry in Sulaimani province. Iraqi J Vet Sci. 2019;33(2):303-309. DOI: 10.33899/ijvs.2019.162995

6. Bitam I, Dittmar K, Parola P, Whiting MF, Raoult D. Fleas and fleaborne diseases. Inter $\mathrm{J}$ Infect Dis. 2010;14:667-676. DOI: 10.1016/j.ijid.2009.11.011

7. Hamzaoui BE, Zurita A, Cutillas C, Parola P. Fleas and flea-borne diseases of North Africa. Acta Trop. 2020;211:105627. DOI: 10.1016/j.actatropica.2020.105627

8. Frank R, Kuhn T, Mehlhorn H, Rueckert S, Pham D, Klimpel S. Parasites of wild rabbits (Oryctolagus cuniculus) from an urban area in Germany, in relation to worldwide results. Parasitol Res. 2013;112(12):4255-66. DOI: 10.1007/s00436-013-3617-7.

9. Cooke D, Fenner F. Rabbit hemorrhagic disease and the biological control of wild rabbits, Oryctolagus cuniculus, in Australia and New Zealand. Wildlife Res. 2002;29:689-706. DOI:10.1071/WR02010

10. Barcena J, Morales M, Vazquez B, Boga JA, Parra F, Lucientes J, Pages A, Sanchez JM, Blasco R, Torres JM. Horizontal transmissible protection against myxomatosis and rabbit hemorrhagic disease by using a recombinant Myxoma virus. J Virol. 2000;74:1114-1123. DOI: $10.1128 /$ jvi.74.3.1114-1123.2000

11. Osacar JJ, Lucientes J, Calvete C, Peribanez MA, Gracia MJ, Castillo JA. Seasonal abundance of fleas (Siphonaptera: Pulicidae, Ceratophyllidae) on wild rabbits in a semiarid area of northeastern Spain. J Med Entomol. 2001;38(3):405-10. DOI: 10.1603/0022-258538.3.405

12. Launay H. Données préliminaires sur lecologie de Xenopsylla cunicularis Smit, 1957 (Siphonaptera, Pulicidae) parasite du lapin de garenne. Ann Parasitol Hum Comp. 1982;57(2):145-63. DOI: 10.1051/parasite/1982572145

13. Manal H. Detection of ectoparasites in different birds. Iraqi J Vet Sci. 2019;33(2):37-41. DOI: 10.33899/ijvs.2019.162896

14. Al- Taee AF, Al- Lahaibi BY. Detection of some species of lice and ticks infestation on local buffalo in Mosul city. Iraqi J Vet Sci. 2019;32(2):43-50. DOI: 10.33899/ijvs.2019.153876

15. Bush AO, Lafferty KD, Lotz JM, Shostak AW. Parasitology meets ecology on its own terms. J Parasitol. 1997;83:575-583. [available at]

16. Hatem AN, Abou Turab MK, Abdul Zahra HK, Muhammad MJ. A survey of chewing lice of some raptors in southern Iraq, with remarks on prevalence and occurrence. Iraqi J Vet Sci. 2020;35(2):239-244. DOI: $10.33899 /$ ijvs.2020.126717.1365

17. Louw JP, Horak IG, Braack LO. Fleas and lice on scrub hares (Lepus saxatilis) in South Africa. Onderstepoort J Vet Res. 1993;60:95-101. [available at]

18. Dik B, Uslu U. Ectoparasites of hares (Lepus europaeus Pallas) in Konya Province, Turkey. Turkish J Vet Anim Sci. 2018;42:65-72. DOI: $10.3906 /$ vet-1706-19

19. Shepherd CH, Nolan F, Lane IL, Edmonds JW. Ectoparasites of the european hare (Lepus europaeus) (pallas) in two regions of Victoria. J Ausr Ent Soc. 1977;16:1-5. DOI: $10.1111 /$ j.14406055.1977.tb00050.x

20. Cooke BD. Notes on the comparative reproductive biology and the laboratory breeding of the rabbit flea Xenopsylla cunicularis Smit (Siphonaptera: Pulicidae). Au J Zool. 1990;38:527-534. DOI: 10.1071/ZO9900527

21. Bessas A, Leulmi H, Bitam I, Zaidi S, Ait OK, Raoult D, Parola P. Molecular evidence of vector-borne pathogens in dogs and cats and their ectoparasites in Algiers, Algeria. Comp Immunol Microbiol Infect Dis. 2016;45:23-28. DOI: 10.1016/j.cimid.2016.01.002

22. Bitam I, Parola P, De La Cruz KD, Matsumoto K, Baziz B, Rolain JM, Belkaid M, Raoult D. First molecular detection of Rickettsia felis in fleas from Algeria. Am J Trop Med Hyg. 2006;74(4):532-5. [available at]

23. Leulmi H, Aouadi A, Bitam I, Bessas A, Benakhla A, Raoult D, Parola P. Detection of Bartonella tamiae, Coxiella burnetii and rickettsiae in arthropods and tissues from wild and domestic animals in northeastern Algeria. Parasit Vectors. 2016;9:27. DOI: 10.1186/s13071-016-1316-9

24. Hornok S, Foldvari G, Rigo K, Meli ML, Toth M, Molnar V, Gonczi E, Farkas R, Hofmann-Lehmann R. Vector-borne agents detected in fleas of the northern white-breasted hedgehog. Vector Borne Zoonotic Dis. Larchmt. 2014;14:74-76. DOI: 10.1089/vbz.2013.1387

25. Marquez FJ. Detection of Bartonella alsatica in European wild rabbit and their fleas (Spilopsyllus cuniculi and Xenopsylla cunicularis) in Spain. Parasit Vect. 2015;8:56. DOI: 10.1186/s13071-015-0664-1

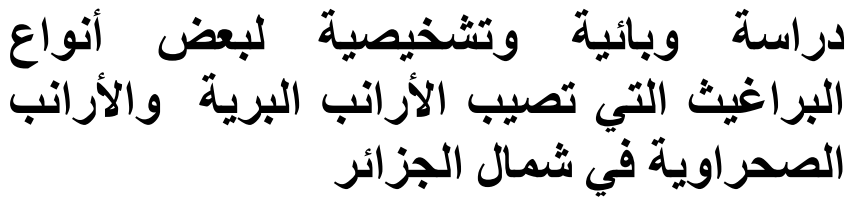

$$
\text { إيمان عمام'، محمد رحال '، كريم رحالَّ و ادير بيطام' }
$$

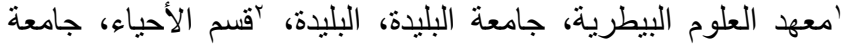

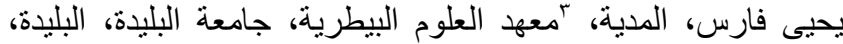

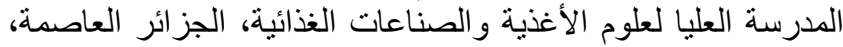
الجزائر

الخلاصة

الأر انب البرية والأر انب الصحر اوية هي عرضة لعدة أنواع مختلفة

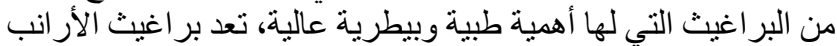

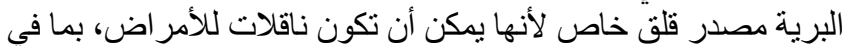

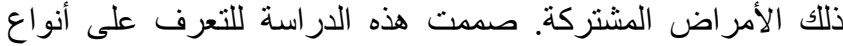
البراغيث التي تصيب هذه الحيوانات مع وصف ديناميكياتها وتقيبيم العوامل التي تؤثر على أهمية الإصنابة في خمس مقاطعات التهات تقع في

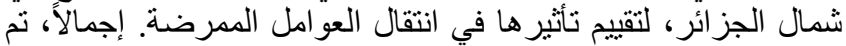

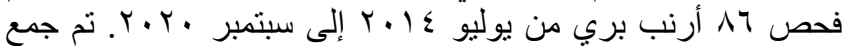
البراغيث من فراء الحيوانات باستخدام الملقط وتم التعرف على عليها

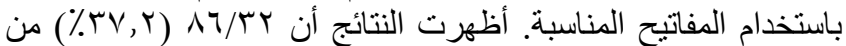

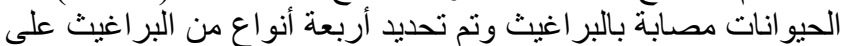

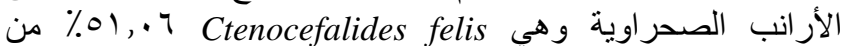

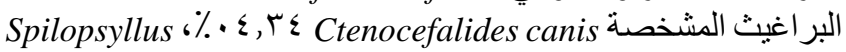
cuniculi

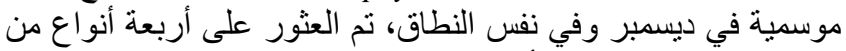

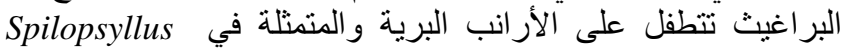
Pulex irritans 6 \% , 70 Ctenocefalides felis $6 \%, 9, \vee$ cuniculi

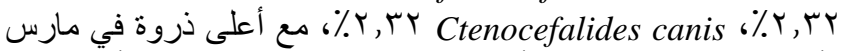

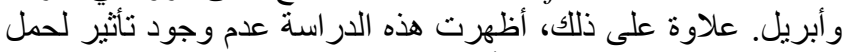

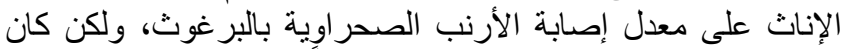

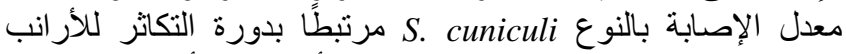

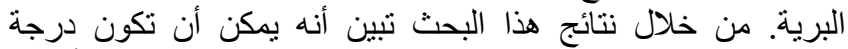

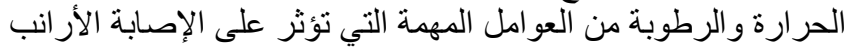
البرية بالبر اغيث. 